\title{
Constructability implementation: a survey in the Malaysian construction industry
}

\begin{abstract}
Twenty-three constructability concepts are identified. Based on these, an industry-wide questionnaire was administrated in Peninsular Malaysia. The respondents were the engineers working with owners, consultants, contractors, subcontractors and construction management firms. The importance, from the viewpoint of the Malaysian engineers, of the constructability concepts and the degree of the actual application of those concepts in the Malaysian Construction Industry is presented so that an insight on constructability implementation can be established. Fieldwork results revealed that the Malaysian engineers showed high acceptance of 22 concepts and rejected the one that relates to the fast-track method of construction. Those engineers accepted the constructability concepts from the theoretical point of view but generally they did not apply these concepts in their practices. The study also concludes that the Malaysian engineers show a wide understanding of the majority of the concepts. However, they did not link those concepts under the umbrella of constructability.
\end{abstract}

